\title{
The Effect of The Touché Therapy On The Anthropometry for Infants In Working Area Service of The PublicHealthCenterPesantren I Kediri.
}

\author{
Heny Kristanto \\ Akper Dharma Husada Kediri
}

\begin{abstract}
The hindrance of infant development is caused by unbearable environmental factor. From year to year, it has been recorded that the infant natal figure is still high, including the natal figure in Kediri - City. Since the high infant natal figure and the infant age as the potential period for development, therefore, it should be optimally cared the development for infant, one of them is done by touché therapy. The objective of the research is to prove that there is a difference between infant cared with anthropometry therapy using touché therapy in working area service of the Public Health Center Pesantren I Kediri. The research plan uses the Randomized Control Trial, the collecting sampling technique uses Total Sampling, and the total sample is 20 infant. Variable research is touché therapy (independent variable) and infant anthropometry (variable dependent). From the result of processing data of anthropometry by using ANOVA test and T test on dependent sample, it can be obtained the significant improvement on the height of the infant (for the treatment group on the $4^{\text {th }}$ week observation, the control group on the $5^{\text {th }}$ week observation and the control group on the $6^{\text {th }}$ week observation). No significant improvement for the head circle of the infant for the treatment control group. The significant improvement on the height is caused by the secretion of Neuro-chemical beta-endorphin the result of the touche therapy treatment, and later it can cause the discretion of hormonal development. The significant improvement on the weight is caused by the stimulus of the nervous vagus that can increase the level of gastric and insulin absorption enzyme. No significant improvement on the head circle of the infantfor the treatment and control groups is caused by the very slow development of the brain cell.
\end{abstract}

Key words: Touché therapy, Anthropometry

\section{LATAR BELAKANG}

Pertumbuhan bayi ditentukan oleh faktor genetik (nature) dan faktor lingkungan (nurture). Dalam pencapaian pertumbuhan yang optimal, setiap bayi mempunyai potensi biologis. Pertumbuhan yang terjadi pada bayi dipengaruhi oleh faktor genetik (biologik), pola makan (psikologik) dan terpenuhinya makanan sesuai kebutuhan (sosial) pada bayi.

Pada tahun 2007 angka kelahiran bayi di Propinsi Jawa Timur mencapai 594.265 kelahiran hidup, sedangkan pada tahun yang sama angka kelahiran bayi di kota kediri berjumlah 3.310 kelahiran. Selanjutnya pada laporan Dinas Kesehatan Kota Kediri, pada bulan September, tercatat 140 kelahiran bayi dan dari sembilan puskesmas di wilayah Kota Kediri, tercatat Puskesmas Pesantren I memiliki angka kelahiran tertinggi, sejumlah 20 kelahiran.

Terapi sentuh mampu menciptakan hubungan kasih sayang yang kuat antara ibu, ayah dan bayi.Ada beberapa mekanisme yang dapat menerangkan pengaruh pijat bayi terhadap berat badan, antara lain pengeluaran beta endorphin dan aktivitas nervusvagus.Selain itu pijatan mampu meningkatkan saraf otonom, yakni saraf - saraf yang antara lain bertanggungjawab atas kelangsungan kerja otot polos, misalnya otot - otot di usus. Saraf otonom merangsang pelepasan hormon yang membantu penyerapan 
makanan, dengan demikian secara tidak langsung terapi sentuh memperbaiki sistempencernaan. (Booklet Nakita, httphonestlyme.multiply.com, diakses tanggal 12 Agustus 2014). Terapi sentuh secara tidak langsung dapat meningkatkan berat badan pada bayi. Dr. Akira Prayudijanto, Sp.A bersama rekan dari Bagian Ilmu Kesehatan Anak FK Unair /RSU Dr. Soetomo Surabaya bahwa terdapat perbedaan pertambahan berat badan dan panjang badan secara bermakna antara bayi prematur yang dilakukan terapi sentuh dengan bayi prematur yang tidak dilakukan terapi sentuh. Pada pengamatan selama 16 minggu yang dilakukan oleh Dr.Ina Rosalina, Sp.A dan rekan dari FK Unpad/RSU Dr. Hasan Sadikin Bandung terhadap 40 bayi (20 bayi laki - laki dan 20 bayi perempuan), bayi cukup bulan dan normal, berat badan lahir lebih dari 2.500 gram dan akan diberikan ASI ekslusif hingga minimal 4 bulan, didapatkan kesimpulan bahwa terdapat perbedaan pertumbuhan berat badan bayi yang sangat bermakna antara kelompok pemijatan dan kontrol pada masing - masing jenis kelamin. Berbagai manfaat terapi sentuh yang berhubungan dengan percepatan pertumbuhan pada bayi telah diteliti, diantaranya adalah pengaruh terapi sentuh terhadap aktivitas nervus vagus, sekresi hormon pertumbuhan dan penurunan catecholamine.

\section{METODE PENELITIAN}

Desain penelitian menggunakan Randomized Control Trial. Metode pengambilan sampel penelitian dilakukan dengan sampling jenuh, dengan jumlah sampel 20 bayi. Dilakukan analisis deskriptif dari pengukuran antropometri bayi, baik pada kelompok perlakuan maupun kelompok kontrol, dibandingka hasilnya untuk mengetahui adany. perbedaan antara kelompok perlakuan dan kelompok kontrol. Selanjutnya untuk mengetahui signifikansi perbedaan dari pengukuran antropometri, dilakukan analisis inferensial dengan menggunakan rumusan uji ANOVA untuk membandingkan adanya kenaikan tinggi badan, berat badan dan lingkar kepala bayi. Selanjutnya tabulasi data juga akan dilakukan uji $\mathrm{T}$ pada sampel dependen, untuk membandingkan tinggi badan, berat badan dan lingkar kepala bayi setiap minggu antara kelompok perlakuan dan kelompok kontrol.

\section{HASIL PENELITIAN}

Berdasarkan penelitian, didapatkan data sebagai berikut :

Tabel 1.Perbandingan Tinggi Badan Bayi Kelompok Perlakuan dan Kelompok Kontrol

\begin{tabular}{|c|c|c|c|c|c|c|}
\hline \multirow{3}{*}{$\begin{array}{l}\text { Tinggi } \\
\text { Badan } \\
\text { Kelom } \\
\text { pok } \\
\text { Perlak } \\
\text { uan }\end{array}$} & & $\begin{array}{l}\text { Sum of } \\
\text { Squares }\end{array}$ & $\mathrm{df}$ & $\begin{array}{l}\text { Mean } \\
\text { Square }\end{array}$ & \multirow[t]{2}{*}{$\mathrm{F}$} & \multirow[t]{2}{*}{ Sig. } \\
\hline & $\begin{array}{l}\text { Peng } \\
\text { ukura }\end{array}$ & \multirow[b]{2}{*}{61,723} & \multirow[b]{2}{*}{5} & \multirow[b]{2}{*}{12,345} & & \\
\hline & $\begin{array}{l}\mathrm{n} \\
\text { Ming } \\
\mathrm{gu}\end{array}$ & & & & $\begin{array}{c}10, \\
723\end{array}$ & ,000 \\
\hline \multirow{6}{*}{$\begin{array}{l}\text { Tinggi } \\
\text { Badan } \\
\text { Kelom } \\
\text { pok } \\
\text { Kontro } \\
1\end{array}$} & Galat & 62,167 & 54 & 1,151 & \multirow{6}{*}{$\begin{array}{l}4,5 \\
96\end{array}$} & \multirow{6}{*}{, 001} \\
\hline & Total & 123,890 & 59 & & & \\
\hline & $\begin{array}{l}\text { Peng } \\
\text { ukura }\end{array}$ & & & & & \\
\hline & $\begin{array}{l}\mathrm{n} \\
\text { Ming } \\
\mathrm{gu}\end{array}$ & 23,607 & 5 & 4,721 & & \\
\hline & Galat & 55,480 & 54 & 1,027 & & \\
\hline & Total & 79,087 & 59 & & & \\
\hline
\end{tabular}

Tabel2.Uji BenferoniPada Pertambahan Tinggi Badan Kelompok Perlakuan dan Kelompok Kontrol

\begin{tabular}{|lcccc|}
\hline & & \multicolumn{3}{c|}{ Mean } \\
Dependent & & Difference & \\
Variable & Minggu & Minggu & $(\mathrm{I}-\mathrm{J})$ & Sig. \\
Tinggi Badan & 1 & 2 &,- 5400 & 1,000 \\
$\begin{array}{l}\text { Perlakuan } \\
\text { Tinggi Badan }\end{array}$ & 1 & 2 &,- 24000 & 1,000 \\
Kontrol & & & & \\
\hline
\end{tabular}


Tabel3.Uji Perbedaan Tinggi Badan Kelompok Perlakuan dan

Kelompok Kontrol

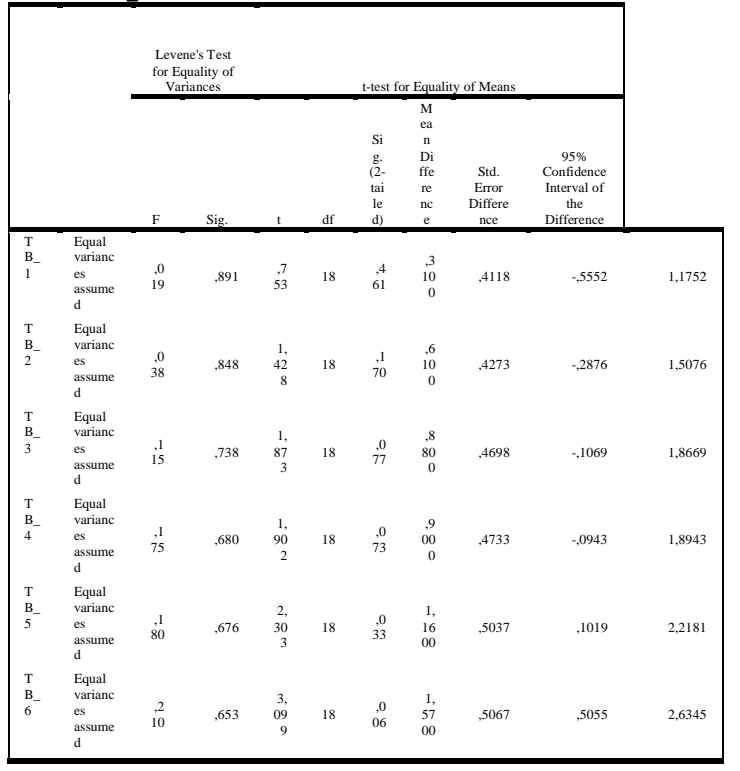

Tabel4.Perbandingan Tinggi Badan Pretest dan Berat Badan Perlakuan Pada Kelompok Perlakuan

\begin{tabular}{|c|c|c|c|c|}
\hline & & $\begin{array}{l}\text { Paired } \\
\text { Differen }\end{array}$ & & \\
\hline & & Mean & Mean & $\begin{array}{l}\text { Sig. (2- } \\
\text { tailed) }\end{array}$ \\
\hline Pair 1 & $\begin{array}{l}\text { PreTB_P } \\
- \text { TB_P1 }\end{array}$ & $-1,9700$ & $-11,771$ & ,000 \\
\hline Pair 2 & $\begin{array}{l}\text { PreTB - } \\
\text { TB_P2 }\end{array}$ & $-2,5100$ & $-12,298$ & ,000 \\
\hline Pair 3 & $\begin{array}{l}\text { PreTB - } \\
\text { TB_P3 }\end{array}$ & $-3,0700$ & $-12,998$ & ,000 \\
\hline Pair 4 & $\begin{array}{l}\text { PreTB - } \\
\text { TB_P4 }\end{array}$ & $-3,6400$ & $-14,140$ & ,000 \\
\hline Pair 5 & $\begin{array}{l}\text { PreTB - } \\
\text { TB_P5 }\end{array}$ & $-4,2200$ & $-15,781$ & ,000 \\
\hline Pair 6 & $\begin{array}{l}\text { PreTB - } \\
\text { TB_P6 }\end{array}$ & $-4,9800$ & $-18,859$ & ,000 \\
\hline
\end{tabular}

Tabel 5 Pertambahan Berat Badan Pada Kelompok Perlakuan Dan Kelompok Kontrol

\begin{tabular}{|c|c|c|c|c|c|c|}
\hline \multirow{3}{*}{$\begin{array}{l}\text { BeratBadan } \\
\text { Perlakuan }\end{array}$} & \multirow{4}{*}{$\begin{array}{l}\text { Pengukuran } \\
\text { Minggu } \\
\text { Galat }\end{array}$} & $\begin{array}{l}\text { Sum of } \\
\text { Squares }\end{array}$ & df & $\begin{array}{c}\text { Mean } \\
\text { Square }\end{array}$ & \multirow{3}{*}{$\begin{array}{c}\mathrm{F} \\
44,0 \\
23\end{array}$} & \multirow{3}{*}{$\begin{array}{l}\text { Sig. } \\
, 000\end{array}$} \\
\hline & & 7534833,333 & 5 & 1506966,6 & & \\
\hline & & & & 67 & & \\
\hline & & 1848500,000 & 54 & 34231,481 & \multirow{5}{*}{$\begin{array}{c}22,8 \\
36\end{array}$} & \multirow{5}{*}{, 000 } \\
\hline \multirow{4}{*}{$\begin{array}{l}\text { BeratBadan } \\
\text { Kontrol }\end{array}$} & Total & 9383333,333 & 59 & & & \\
\hline & $\begin{array}{l}\text { Pengukuran } \\
\text { Minggu }\end{array}$ & 5294500,000 & 5 & $\begin{array}{r}1058900,0 \\
00\end{array}$ & & \\
\hline & Galat & 2504000,000 & 54 & 46370,370 & & \\
\hline & Total & 7798500,000 & 59 & & & \\
\hline
\end{tabular}

Tabel 6Uji BenferoniPada Pertambahan Berat Badan Kelompok Perlakuan dan Kelompok Kontrol

\begin{tabular}{|lcccc|}
\hline $\begin{array}{l}\text { Dependent } \\
\text { Variable }\end{array}$ & Minggu & Minggu & $\begin{array}{c}\text { Mean } \\
\text { Difference } \\
\text { BeratBadan }\end{array}$ & Sig. \\
$\begin{array}{l}\text { Perlakuan } \\
\begin{array}{l}\text { BeratBadan } \\
\text { Kontrol }\end{array}\end{array}$ & 1 & 2 & $-190,000$ &, 383 \\
\hline
\end{tabular}

Tabel 7 Uji Perbedaan Berat Badan Kelompok Perlakuan dan Kelompok Kontrol

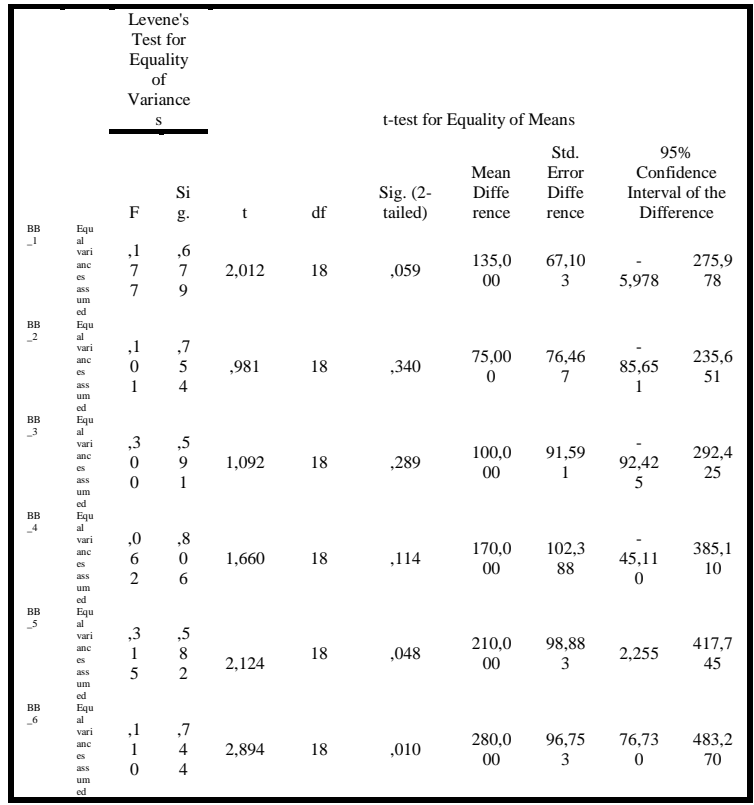

Tabel 8Perbandingan Berat Badan Awal dan Berat Badan Selama Perlakuan

\begin{tabular}{|c|c|c|c|c|}
\hline & & $\begin{array}{c}\text { Paired } \\
\text { Differences }\end{array}$ & $t$ & $\begin{array}{l}\text { Sig. (2- } \\
\text { tailed) }\end{array}$ \\
\hline Pair 1 & PreBB_P - BB_P1 & $-1265,000$ & $-23,524$ & ,000 \\
\hline Pair 2 & PreBB_P - BB_P2 & $-1455,000$ & $-26,701$ & , 000 \\
\hline Pair 3 & PreBB_P - BB_P3 & $-1655,000$ & $-27,036$ & ,000 \\
\hline Pair 4 & PreBB_P - BB_P4 & $-1880,000$ & $-25,584$ & ,000 \\
\hline Pair 5 & PreBB_P - BB_P5 & $-2075,000$ & $-28,376$ & , 000 \\
\hline Pair 6 & PreBB_P - BB_P6 & $-2300,000$ & $-34,718$ & , 000 \\
\hline
\end{tabular}


Tabel 9Peningkatan Lingkar Kepala Pada Kelompok Perlakuan Dan Kelompok Kontrol

\begin{tabular}{|c|c|c|c|c|c|c|}
\hline \multirow{2}{*}{$\begin{array}{l}\text { LK } \\
\text { Kelompok } \\
\text { Perlakuan }\end{array}$} & \multirow{2}{*}{$\begin{array}{l}\text { Pengukuran } \\
\text { Minggu }\end{array}$} & $\begin{array}{l}\text { Sum of } \\
\text { Squares }\end{array}$ & $\mathrm{df}$ & $\begin{array}{l}\text { Mean } \\
\text { Square }\end{array}$ & \multirow{2}{*}{$\begin{array}{c}\mathrm{F} \\
10,3\end{array}$} & \multirow{2}{*}{$\begin{array}{l}\text { Sig. } \\
000\end{array}$} \\
\hline & & 20495 & 5 & 4099 & & \\
\hline \multirow{5}{*}{$\begin{array}{l}\text { LK } \\
\text { Kelompok } \\
\text { Kontrol }\end{array}$} & Galat & 21,484 & 54 & ,398 & \multirow{5}{*}{$\begin{array}{c}19,9 \\
35\end{array}$} & \multirow{5}{*}{,000 } \\
\hline & Total & 41,979 & 59 & & & \\
\hline & Pengukuran & & & & & \\
\hline & Galat & 8,910 & 54 & ,165 & & \\
\hline & Total & 25,356 & 59 & & & \\
\hline
\end{tabular}

Tabel 10Peningkatan Lingkar Kepala Pada Kelompok Perlakuan Dan Kelompok Kontrol

\begin{tabular}{|c|c|c|c|c|}
\hline $\begin{array}{l}\text { Dependent } \\
\text { Variable }\end{array}$ & Minggu & Minggu & $\begin{array}{c}\text { Mean } \\
\text { Differenc } \\
\text { e (I-J) }\end{array}$ & Sig. \\
\hline $\begin{array}{l}\text { LK Kelompok } \\
\text { Perlakuan }\end{array}$ & 1 & 2 &,- 2200 & 1,000 \\
\hline $\begin{array}{l}\text { LK Kelompok } \\
\text { Kontrol }\end{array}$ & 1 & 2 &,- 2300 & 1,000 \\
\hline
\end{tabular}

Tabel 11Uji tPerbedaan Lingkar Kepala Kelompok Perlakuan dan Kelompok Kontrol

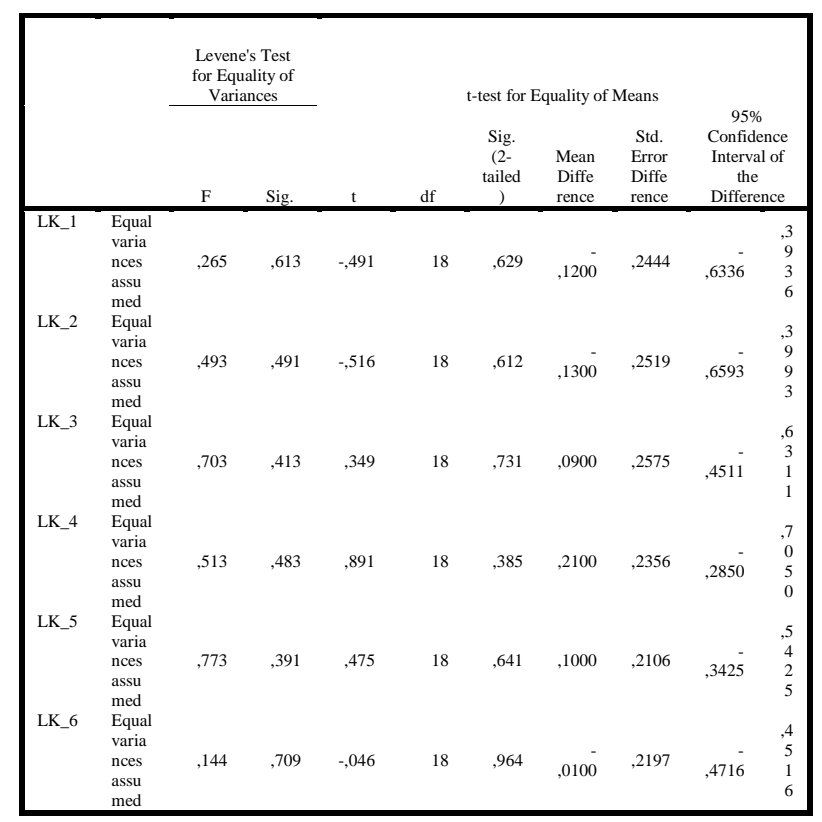

Tabel 12Perbandingan Lingkar Kepala Pretest dan Berat Badan Selama Perlakuan

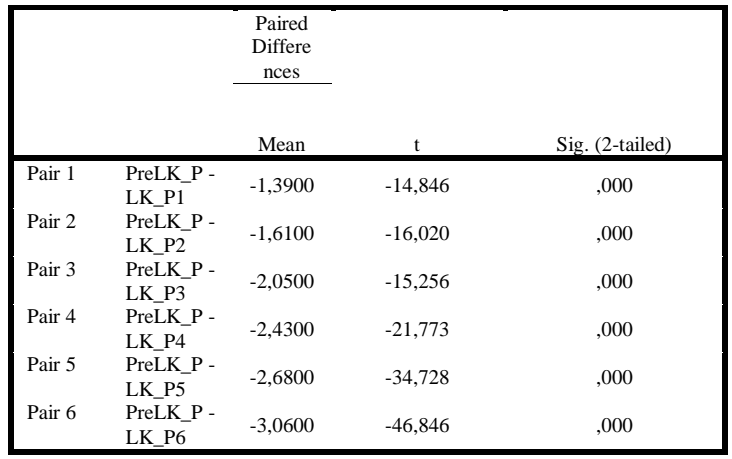

\section{PEMBAHASAN}

Pembahasan menguraikan tentang hasil penelitian tentang pengaruh terapi sentuh yang dilakukan secara teratur terhadappeningkatan antropometri (berat badan, tinggi badan, lingkar kepala) bayi, dan akan dibahas yang berkaitan dengan teori yang meliputi :

1. Tinggi badan pada bayi yang dilakukan dan tidak dilakukan terapi sentuh

Menurut Schanberg dalam buku pedoman pijat bayi, disebutkan bahwa pengurangan sensasi taktil akan meningkatkan pengeluaran suatu neurochemical beta-endorphine, yang akan mengurangi pembentukan hormon pertumbuhan karena menurunya jumlah dan aktivitas ODC (Ornithine Decarboxylase) jaringan. Terapi sentuh yang dilakukan pada bayi, menyebabkan disekresikannya serotonin. Dalam buku ajar fisiologi kedokteran disebutkan bahwa serotonin yang disekresikan oleh sistem saraf dalam hipotalamus akan meningkatkan kecepatan sekresi hormon pertumbuhan dan pada akhirnya menyebabkan peningkatan pertumbuhan bayi, termasuk tulang (Guyton, A.C. 1997: 146). 
2. Berat badan pada bayi yang dilakukan dan tidak dilakukan terapi sentuh.

Menurut Field dan Schanberg dalam buku pedoman pijat bayi, disebutkan bahwa pada bayi yang dipijat akan mengalami peningkatan tonus nervus vagus (saraf otak ke-10) yang akan meningkatkan kadar enzim penyerapan gastrin dan insulin. Dengan demikian, penyerapan makanan akan menjadi lebih baik (Roesli U. 2008: 86). Penyerapan makanan yang lebih baik akan menyebabkan bayi lebih cepat lapar sehingga akan lebih sering menyusu. Dengan demikian karena asupan ASI yang lebih sering, menyebabkan bayi yang dilakukan terapi sentuh mengalami percepatan peningkatan berat badan yang signifikan dibandingkan bayi yang tidak dilakukan terapi sentuh.

3. Lingkar kepala pada bayi yang dilakukan dan tidak dilakukan terapi sentuh

Kira - kira $50 \%$ dari pertumbuhan otak terjadi pada tahun pertama kehidupan, 20\% terjadi pada tahun kedua. Akan tetapi walaupun volume otak tidak menggambarkan tingkat kecerdasan, pada bayi yang dilakukan terapi sentuh akan menjadikan bayi dapat tidur lebih lelap dan meningkatkan kesiagaan (alertness) atau konsentrasi. Hal ini disebabkan, karena pijatan dapat mengubah gelombang otak. Pengubahan gelombang otak terjadi dengan cara menurunkan gelombang alpha dan meningkatkan gelombang beta serta tetha( Roesli U. 2008:87)

\section{KESIMPULAN}

1. Terdapat perbedaan kecepatan pertumbuhan (tinggi badan) antara kelompok perlakuan dan kelompok kontrol, dari hasil pengolahan data pertumbuhan tinggi badan pada kelompok perlakuan didapatkan pertambahan tinggi badan secara signifikan pada minggu ke 4 sedangkan pada kelompok kontrol didapatkan pertambahan tinggi badan signifikan pada minggu ke 5 .

2. Terdapat perbedaan kecepatan pertumbuhan (berat badan) antara kelompok perlakuan dan kelompok kontrol dan didapatkan perbedaan secara signifikan berat badan sebelum dan sesudah perlakuan dari minggu ke 1 sampai minggu ke 6 .

3. Pada pengukuran lingkar kepala bayi antara kelompok perlakuan dan kelompok kontrol ada peningkatan lingkar kepala tetapi tidak ditemukan adanya perbedaan yang signifikan mulai minggu ke 1 sampai dengan minggu ke 6 pada kedua kelompok.

\section{SARAN}

1. Institusi pendidikan Kebidanan dan Keperawatan, hendaknya dapat memasukkan terapi sentuh sebagai muatan lokal pada kurikulum pendidikan.

2. Secara berkesinambungan hendaknya dilakukan pelatihan tentang terapi sentuh yang bertempat di posyand diikuti oleh bidan dan kader posyanc balita di setiap wilayah kerja puskesmas.

3. Bidan atau perawat yang telah mengikuti pelatihan dan memiliki sertifikat pelatihan terapi sentuh, dapat membentuk komunitas yang beranggotakan ibu muda, ibu hamil, dan ibu nifas untuk diberikan pelatihan terapi sentuh.

\section{DAFTAR PUSTAKA}

Becker, Jordy. 2007. Terapi Pijat Memijat Diri Sendiri Guna Memperoleh Kesehatan Fisik Dan Psikis. Jakarta : Prestasi Pustaka

Depkes RI. 1995. Sosial Budaya Dasar. Jakarta : Depkes

Guyton Arthur, Hall John E. 1997. Buku Ajar Fisiologi Kedokteran. Jakarta : EGC 
Heath, Alan,dr. Dan Brainbridge, Nicki. 2006. Baby Massage. Jakarta : Dian Rakyat

Hidayat A.A. 2005. Pengantar Ilmu Keperawatan Anak 1, Jakarta : Salemba Medika

M. Enny. 2007. Seri Perawatan Bayi Bagi Pasangan Muda. Yogyakarta : Bukulaela

Machfoedz, Ircham. 2007. PendidikanKesehatan Bagian Dari Promosi

Kesehatan. Yogyakarta

Fitramaya

Miles, Matthew B. Dan A. Michael Huberman. Analisis Data Kualitatif : Buku Sumber Tentang Metode - metode Baru.Jakarta : UI Press

Moberg,K, Widstrom,A.M., Marchini,G, Winberg,J, 1987, Release of GI hormones in Mother and Infant by Sensory Stimulation, http://www6.miami.edu/touchresearch/massage.htm, diaksestanggal[20 Nopember 2008]

Nana Syaodih Sukmadinata, Prof.Dr. 2007. Metode Penelitian Pendidikan. Bandung : Remaja Rosdakarya

Notoatmodjo Soekidjo. 2005. Promosi Kesehatan Teori dan Aplikasi. Jakarta : Rineka Cipta

Patilima, Hamid. 2007. Metode Penelitian Kualitatif. Bandung : Alfabeta
Purwanto, Heri. 1999. Pengantar Perilaku Manusia untuk Keperawatan. Jakarta : EGC

Roesli, Utami. 2008. Pedoman Pijat Bayi Edisi Revisi. Jakarta : Trubus Agriwidya

Rosalina, Ina. 2007. Fisiologi Pijat Bayi. Bandung : Trikarsa Multi Media

Ross, Susan. 2006. Birth Right. Jakarta : Trans Media

Sacharin R.M. 2004. Prinsip Keperawatan Pediatrik. Edisi Jakarta : EGC

Sari. 2008. gayahidupsehat.http:// www.gayahidupsehatonline.com, diakses tanggal [12Juli 2008]

Soetjiningsih. 2006. Tumbuh Kembang Anak. Edisi 2. Jakarta : EGC 2007.

Promosi Kesehatan dan Ilmu Perilaku. Jakarta : Rineka Cipta

Subakti, Yazid dan Rizki Anggraini, Deri. 2008. Ensiklopedia Calon Ibu. Jakarta : Qultum Media

Sugiyono. 2007. Memahami Penelitian Kulaitatif. Bandung : Alfabeta 2008.

Metode

Penelitian Kuantitatif, Kualitatif dan $R \& D$. Bandung : Alfabeta

Yin, Robert. K. 2008. Studi Kasus Desain dan Metode. Jakarta : PT. Raja Grafindo Persada 